\title{
Key directions of development of measures to improve the reliability of electrical power systems
}

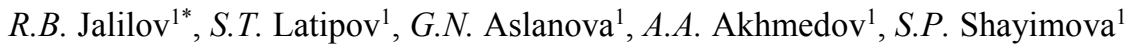 \\ ${ }^{1}$ Bukhara Engineering-Technological Institute
}

\begin{abstract}
The article covers the study of measures aimed to improving the reliability of electrical power systems at the present stage. It considers the integration of the global electricity industry. The article analyzes the latest technical work in the field of automation, such as Smart Grid and intelligent power systems.
\end{abstract}

\section{Introduction}

Patterns of changes in the conditions for the development and functioning of electric power systems (EPS) lead to significant transformations in the structure of systems and their modes of operation. These transformations are caused by a number of objective factors that determine the shape of EPS of the future. They continue to increase the scale of EPS, expanding the territories they serve, uniting various EPS for joint work with the formation of interregional, interstate and intercontinental energy associations $[1,3,4,9]$. The formation of interstate electrical connections (ISEC), associations (ISEA) and markets is a global integration process that has been going on in various regions of the world for almost a century. The chronology of the development of the ISEA since the first quarter of the twentieth century is detailed considered in [9-13 and 1621].

\section{Integration of the global electrical power industry}

In studies [9-12], it is noted that the ISEA of the UES / EES is currently very poorly integrated. It should be expected that in frame of the formation of a common economic space in the integration projects of the Customs Union and the EAEU, the disintegration trend in the electric power industry of the post-Soviet space will finally change to integration trend, which, as was evident from the consideration of world experience, corresponds to the global trend.

Recently, the problem of the formation of the Global Super-Energy Association has been raised again, and promising electric power mega-projects that will make up its important elements are being considered [9]. In the zone of influence of the Unified Energy System of Russia and the ISEA of the OEC / UES, various interstate electric power projects, that actually determine the direction of Russia's integration into the electric power space of Eurasia, are being implemented (Fig. 1) [9]. Among them, the interesting one is the CASAREM project - Central Asia South Asia Regional Electricity Market (SHPP project between the countries of Central and South Asia).

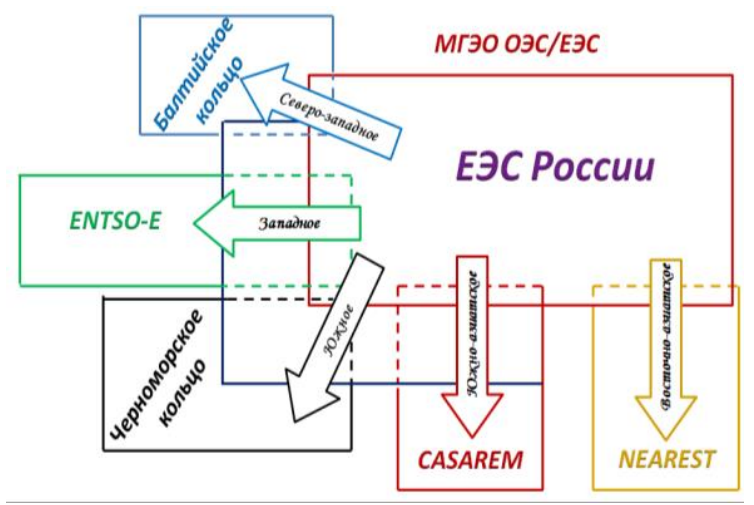

Source: ISEM SB RAS

Fig. 1. Directions for the integration of the UES of Russia into the Eurasian ISEA [9].

UES of Russia (as noted in [9]), as well as UES of Uzbekistan, participating in electric power integration projects with neighboring countries, can become the link between national and regional EPS in a significant part of Europe and Asia, contributing to the formation of the Eurasian transcontinental energy association. In the end, this helps to increase the reliability of power systems in the Central Asian region.

Given the new technologies in converting technology based on power electronics, reducing costs, increasing reliability and ensuring high controllability of direct current power transmission, they will receive significant development in the transmission electric network. At the same time, the widespread use of devices that form flexible AC power transmission (FACTS) based on the use of power electronics will radically increase the controllability of the AC transmission network [3]. New technologies, including the use of FACTS devices, will

* Corresponding author: zhalilov.rashid@mail.ru 
significantly increase the reliability and controllability of the distribution electric network.

\section{The use of energy storage systems in modern energy systems}

Another direction in the development of measures to increase the reliability of EPS is the active introduction of energy storage systems (ESS) [13]. Taking into account that the new economy of the future is neoindustrialization, based on a combination of large installations and distributed generation, power and information processes, physical and intellectual systems, in the near future energy will be combined systems designed for a wide range of energy services offered to consumers at the right time and necessary quality.

Especially small (in terms of unit capacity) generation is rapidly developing, which provides a more complete use of local (both renewable and other alternative) resources. At the same time, a consumer can simultaneously become a producer of electricity, which must either be accumulated on-site or delivered to the network. In recent years, the development of electric power transmission systems in the world is characterized by their significant complication, increase of their intellectual level, the active introduction of renewable energy sources (RES), distributed generators, end-users with controlled consumption, as well as communication systems and control systems. These changes are designed to provide benefits, such as the ability to meet the objectives of the state policy to diversify the electricity industry and provide consumers with greater choice while ensuring their own electricity supply [2]. However, these transformations encounter certain problems indicated in [13].

\section{Implementation of energy storage systems}

Active implementation of energy storage systems (ESS) in energy systems to some extent will overcome the above problems.

Each energy storage technology is characterized by capital expenditures for its implementation, as well as operating costs. The cost of various ESS and the benefits of their use depend to a large extent on their structure in terms of discharge power (MW) and energy capacity $(\mathrm{MW} \cdot \mathrm{h})$. Independent system operators (ISO), energy companies, sellers and providers of energy storage technologies need actively formulating the rules of the emerging ESS market, as well as operational requirements, in order to achieve maximum economic efficiency from the use of ESS.

Ten key areas represent the predominant use of ESS and are most interesting for potential ESS owners and electricity market operators. Due to the high capital costs for most ESS, it is advisable to use separate devices to perform several tasks simultaneously, corresponding to those areas of application, indicated in the table 1.2.
Table 1. Definition of the main areas of application of ESS at the level of generation and power systems [13]

\begin{tabular}{|l|l|}
\hline \multicolumn{1}{|c|}{ Application } & \multicolumn{1}{c|}{ Description } \\
\hline $\begin{array}{l}\text { Services in the } \\
\text { wholesale electricity } \\
\text { market }\end{array}$ & $\begin{array}{l}\text { ESS installed in the power system for } \\
\text { bidding on the electricity and capacity } \\
\text { market and on the system services } \\
\text { market1) }\end{array}$ \\
\hline $\begin{array}{l}\text { RES integration in } \\
\text { the energy system }\end{array}$ & $\begin{array}{l}\text { ESS installed in the power system and } \\
\text { providing a shift of the maximum } \\
\text { load in time and system services to } \\
\text { ensure parallel operation of renewable } \\
\text { energy with the power system }\end{array}$ \\
\hline $\begin{array}{l}\text { Stationary ESS to } \\
\text { support } \\
\text { transmission and } \\
\text { distribution of } \\
\text { electrical energy }\end{array}$ & $\begin{array}{l}\text { ESS to support the transmission and } \\
\text { distribution of electricity, increasing } \\
\text { the efficiency of the transmission and } \\
\text { distribution network, as well as } \\
\text { savings due to the rejection of the } \\
\text { construction of additional network } \\
\text { facilities }\end{array}$ \\
\hline $\begin{array}{l}\text { Mobile ESS to } \\
\text { support power } \\
\text { transmission and } \\
\text { distribution }\end{array}$ & $\begin{array}{l}\text { Mobile ESS to support power } \\
\text { transmission and distribution while } \\
\text { delaying the entry of transmission and } \\
\text { distribution network facilities in many } \\
\text { places as needed. }\end{array}$ \\
\hline $\begin{array}{l}\text { 1) only large ESS operating simultaneously in the electricity } \\
\text { market and in the system services market }\end{array}$ \\
\hline
\end{tabular}

Table 2. Identification of the main ESS applications at the level of transmission and distribution network [13]

\begin{tabular}{|l|l|}
\hline \multicolumn{1}{|c|}{ Application } & \multicolumn{1}{c|}{ Description } \\
\hline $\begin{array}{l}\text { ESS in distribution } \\
\text { networks }\end{array}$ & $\begin{array}{l}\text { Centrally managed, modular } \\
\text { systems providing increased } \\
\text { reliability of power supply, } \\
\text { support for transmission and } \\
\text { distribution networks, and } \\
\text { potentially system services }\end{array}$ \\
\hline $\begin{array}{l}\text { ESS aggregated by } \\
\text { energy companies } \\
\text { providing electricity } \\
\text { in the retail electricity } \\
\text { market. }\end{array}$ & $\begin{array}{l}\text { ESS, installed and serviced living } \\
\text { spaces, aggregated and centrally } \\
\text { managed for distribution systems. }\end{array}$ \\
\hline $\begin{array}{l}\text { ESS to ensure the } \\
\text { quality of electricity } \\
\text { and reliability in the } \\
\text { supply of electricity to } \\
\text { commercial and } \\
\text { industrial consumers }\end{array}$ & $\begin{array}{l}\text { ESS to ensure the quality and } \\
\text { reliability of electricity supply to } \\
\text { commercial and industrial } \\
\text { consumers }\end{array}$ \\
\hline $\begin{array}{l}\text { ESS for } \\
\text { power } \\
\text { management } \\
\text { for } \\
\text { commercial } \\
\text { and industrial } \\
\text { consumers. }\end{array}$ & $\begin{array}{l}\text { ESS to reduce the time of use of } \\
\text { the energy supplied from the } \\
\text { power system during hours of } \\
\text { maximum load of electricity by } \\
\text { commercial and industrial } \\
\text { consumers. }\end{array}$ \\
\hline
\end{tabular}

The European Association for the Development of Energy Storage Technologies, together with the European Alliance for Energy Research, has developed a roadmap for the development of ESS until 2030 [14]. The tables 5 and 6 [13] provide information from this roadmap for lithium-ion batteries and flow redox storage. These two types of electrochemical ESS are by far the most common in the world. 


\section{The development of smart energy systems taking into account the reliability factor}

The idea of intellectualization of EPS is close to the principles of cybernetic control, and this is largely due to advances in engineering and technology [15-20, 22-24]. Initially, the concept of constructing intelligent EES (IES) in foreign countries - Smart Grid - was aimed at the development of power supply systems for end consumers with the installation of control systems and power consumption (Smart metering) and providing the ability to connect distributed power sources to the EES, first turn, autonomous wind turbines and photovoltaic panels. Today, the ideology of the development of Smart Grid includes almost all the main areas of activity in the electric power industry and the corresponding technological and information-communication bonds between them $[15,22,24]$.

The term Smart Grid has not received a unified definition. To characterize the diversity of the meaning of this concept, a series of definitions of the leading organizations of the USA (EPRI, IEEE) and Western Europe in the field of developing the Smart Grid ideology are given in [15].

Smart Grid refers to the modernization of the power supply system aimed at the ability to monitor, protect, optimize the functioning of all elements of EPS centralized and distributed generation, high-voltage transmission and distribution networks, industrial consumers and building management systems, energy storage devices, end-users, electrical transport, household appliances [17].

Smart grid is a combination of energy, communication and information technology for an improved power infrastructure that enables continuous evolution of end use devices [18].

Smart Grid is an electric network that can costeffectively combine the modes and actions of all connected users - generators, consumers and their associations, to ensure a cost-effective and sustainable energy system with low losses, high quality and reliability of power supply and safety [19].

The Smart Grid functional model, presented by the USA National Institute of Standards and Technology (NIST) in 2009, identifies the main areas of activity in the electric power industry, represented by seven areasdomains, combined by technological and communication links (Fig. 2.) [19]:

- Bulk Generation;

- Transmission;

- Distribution;

- Operations;

- Customer;

- Markets;

- Service provider.

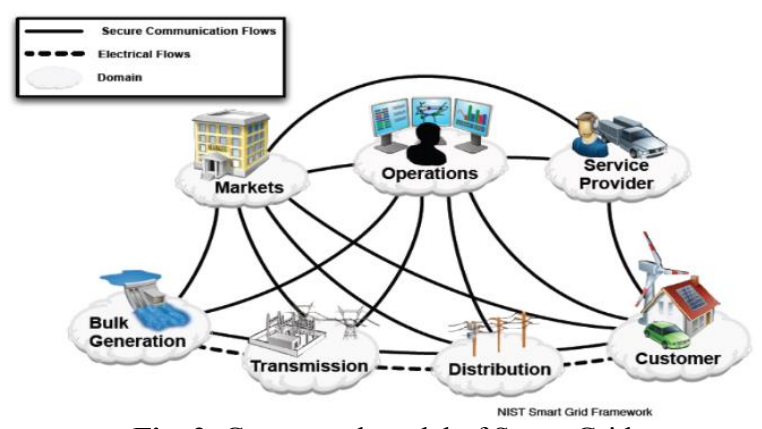

Fig. 2. Conceptual model of Smart Grid - secure communication currents - - - electric currents

The issues of standardization in the formation of intellectual EPS are in the focus of attention of leading international organizations and institutions $[15,16,19-$ 21]:

- International Electrotechnical Commission

- International Council for Large Electrical Systems (CIGRE);

CENELEC);

- European Standards Committees (CEN and

- European

Telecommunications

Standardization Institute (ETSI);

- Institute of Electrical and Electronics Engineers (IEEE);

- US National Institute of Standards and Technology (NIST);

- Electric Power Research Institute (EPRI).

As noted in [15, 17], a number of international standards on which the design and operation of Smart Grid elements can be based already exist (Fig. 3.).

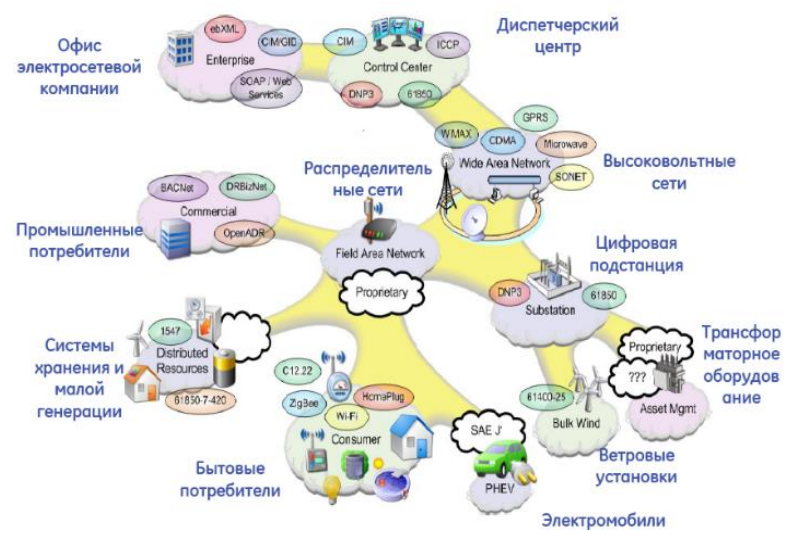

Fig. 3. Standards for Smart Grid.

For example, these are standards for the IEC 61850 series digital substation, IEC 61970/61968 standards for the CIM common information model, IEEE 802.15.4 standard for interacting with consumer devices using the ZigBee protocol, etc.

Technical Committee 57 of IEC develops international standards (Fig. 4) for EMS, SCADA, automation of distribution networks, information exchange, real-time control, etc., which will be used in the planning, use and operation of the IES [20]. 


\section{Discussion}

Another important new factor for future EPSs is the emergence of active consumers who independently manage their own energy consumption depending on price conditions in the retail electricity market by transferring electricity consumption by some power consumers from periods with a high price of electricity to periods with a low price.

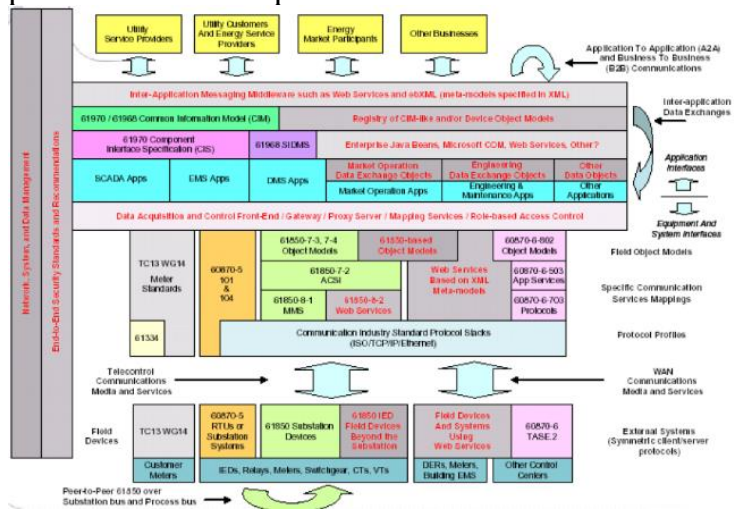

Fig. 4. IEC Standards for Control Systems.

Such a load control of active consumers, independent of the dispatch schedule, creates problems for managing the EPS modes due to the uncertainty in the power consumption of active consumers. Therefore, the interaction between EPS and consumers on joint control of system modes using the regulatory capabilities of consumers is promising [3].

\section{Conclusion}

1. The proposals given in this article open the prospect of further research on an extremely important problem in assessing the reliability and safety of energy facilities and systems.

2. With the development of future EPS on the technological base of the intelligent energy system, new problems will become aggravated in the future, related to the need to strengthen coordination of control of EPS modes at various levels, increase management efficiency, and ensure the reliability of the control system for EPS modes. The issues of information and cyber security during monitoring and control of EPS are especially acute [16].

3. All of the mentioned above requires serious indepth research to study the properties of future EPS, to develop principles and methods for their formation, taking into account changing conditions, as well as dispatch and automatic control systems for future EPSs.

\section{References}

1. Allaev K.R. Power industry of Uzbekistan and the world. T.: Fan va texnologiya, 2009, p.463.

2. Fortov V.E. Energy of the future based on breakthrough technologies as the basis of a new energy civilization // Materials of the XXIV International scientific, technical and practical conference "Prospects for the development of the electric power industry and high-voltage electrical equipment. Switching devices, conversion equipment, microprocessor control systems and security". November 28 - 29, 2016. Innovative power industry - 21. [Electronic resource]. URL: http://www.energy-strategy.ru/projects/energy_21.htm (date of the application: 20.04.2019).

3. Voropay N.I., Osak A.B. New properties of future power systems. // The same address [Electronic resource]. URL:http:// www. energy strategy. ru/projects/-energy_21.htm (date of the application: 20.04.2019).

4. V.A. Ovseychuk, V.A. Nepomnyashi. Rationing the reliability and quality of power supply to consumers // Innovation and Expertise. -2016. Volume 1/16. C.178185. [Electronic resource]. URL:http: //www.energystrategy. ru/projects/energy_21.htm (date of the application: 20.04.2019).

5. Voropay N.I., Domyshev A.V., Nepomnyashchy V.A. Models and methods for investigating the operational reliability of electric power systems // Reliability of energy systems: Problems, models and methods of their solvation. Novosibirsk: Science, 2014, p. 57-73.

6. Voropai N.I., Efimov D.N., Kurbatsky V.G., Panasetskiy D.A., Tomin N.V. ISEM SO AN // Algorithms of survivability and self-restoration of intelligent electric power systems [Electronic resource]. URL:http://www.energystrategy.ru/ projects/ energy_21. htm (date of the application: 20.04.2019).

7.Trends in microgrid control. IEEE-PES Task Force on Microgrid Control / D.E.Olivares, A.Mehrizi-Sani, A.H.Etemadi, e.a. // IEEE Transactions on Smart Grid, 2014, Vol.5, No.4, p. 1905-1919.

8 . Kitushin. Reliability of energy systems. Part 1. Theoretical Foundations: Textbook.-Novosibirsk: Publishing House of NSTU. 2003, p.256.

9. Podkovalnikov S.V., Savelyev V.A., Chudinova L.Yu. Integration of global electricity industry is the path to creating a global energy associations

// [Electronic resource]. URL:http://www. energystrategy. ru/projects/ energy_21.htm (date of the application: 20.04.2019).

10. Global Energy Network Institute - GENI - URL: http://www.geni. org/index.html .

11. Electricity of the CIS 2003-2013 // Executive Committee of the CIS Electric Power Council, 2015 172 c. - URL: http://energo-cis.ru.

12. 2013 Year's Annual Report of GSE // Georgian State Electro system, 2014. - 39 c. - URL:

http://www.gse.com.ge/new/ wpcontent/uploads /2014/07/SSA_ANNUAL_2013_FOR_WEB.pdf. 13. Kucherov Yu.N., Novikov N.P. The main trends in the development and application of energy storage systems in modern energy systems //[Electronic resource]. URL:http://www. Energy-strategy. ru/projects/ energy_21.htm (date of the application: 20.04.2019).

14. Joint EASE/EERA Recommendation for a European Energy Storage Technology Development Roadmap Towards 2030, Final Report, March 2013. 
15. Clark W. Gellings. Let's Build a Global Power Grid // IEEE Spectrum.- 2015. - July -

URL:http://spectrum.ieee.org/energy/the-smartergrid/lets-build-a-global-power-g.

16. Kucherov Yu.N., Fedorov Yu.G. Features of the development of intelligent power systems taking into account the reliability factor // Electronic resource]. URL:http://www. Energy-strategy. ru/projects/ energy_ 21.htm (date of the application: 20.04.2019).

17. Estimating the Costs and Benefits of the Smart Grid / EPRI

Technical report No.1022519, 2011. - 162 c.

18. IEEE Std 2030-2011 Guide for Smart Grid Interoperability of

EnergyTechnology and Information Technology Operation with the Electric Power System (EPS), EndUse Applications, and Loads. -126 c.
19. European Technology Platform Smart Grids Strategic Deployment

Document for Europe's Electricity Networks of the Future, 2010. - 69 c.

20. Technical and Commercial Standardisation of DER microGrid

Components / CIGRE TB 423, WG C6.10, 2010. $129 \mathrm{c}$.

21. Reliability Standards Set / NERC, 2010. - 1074 c.

22. Jalilov R.B. Prerequisites for the creation of automated industrial energy supply management systems // Chief Power Engineer, 2006, No.6, p.41-43.

23. Jalilov R.B. Digital relays: regulatory framework for use, brief description, market overview // Electrical equipment, 2008, No.2, p.7-11.

24. Jalilov R.B. A new approach to the creation of an intelligent automation substation // Industrial Energy, 2008, No.4, p.15-18.

Use A4 paper size $(210$ x $297 \mathrm{~mm})$ and adjust the margins to those shown in Table 1. The final printed area will be 172 x $252 \mathrm{~mm}$. 